\title{
Tendencje rozwojowe, wytyczne dla projektowania i kryteria oceny układów biegowych wagonów osobowych przeznaczonych do wysokich prędkości
}

\begin{abstract}
$W$ artykule przedstawiono aktualny stan jak również tendencje rozwojowe w uktadach biegowych przeznaczonych dla wagonów osobowych do wysokich prędkości, większych lub równych 250 $\mathrm{km} / \mathrm{h}$. Zwrócono uwage na aktualnie obowiqzujace przepisy, które musza spetnione, aby zrealizować ruch pociagów osobowych z wysokimi prędkościami. Przedstawiono podstawowe parametry stużace do oceny układów biegowych, do jakich zalicza się masę własna, masę nieusprężynowana, emisję hatasu podczas jazdy do otoczenia,, technologie wykonania itp. Artykut powstat w ramach projektu badawczo-rozwojowego $\mathrm{nr}$ R10 041 02, finansowanego przez Ministerstwo Nauki $i$ Szkolnictwa Wyższego ze środków budżetowych na naukę na lata 2007:2009 pt.,, Wózek pasażerskiego pojazdu kolejowego typu $Z$ o prędkości $250 \mathrm{~km} / \mathrm{h}$ i możliwości modyfikacji do prędkości $300 \mathrm{~km} / \mathrm{h}$ ”.
\end{abstract}

\section{Wstęp}

Pociagi osobowe składające się $\mathrm{z}$ wagonów osobowych, ciagnionych przez lokomotywę i przystosowanych do wysokich prędkości $230 \div 250 \mathrm{~km} / \mathrm{h} \mathrm{z}$ opcją do przystosowania do prędkości powyżej 300 $\mathrm{km} / \mathrm{h}$, przeżywaja renesans na wszystkich europejskich zarządach kolejowych, choć wcześniejsze prognozy nie dawały większych szans na rozwój tego rodzaju środka transportowego, zwłaszcza gdy bierze się pod uwagę dynamiczny rozwój zespołów trakcyjnych, przystosowanych do wysokich prędkości [1]. Z najnowszych tendencji rozwojowych wynika, że pociagi tego rodzaju będą istotna podporą kolejowego ruchu dalekobieżnego w XXI-szym wieku. Do podstawowych zalet wagonów osobowych na przykładzie wagonów typu „Viaggio Comfort” zastosowanych w ruchu dalekobieżnych można zaliczyć: elastyczność eksploatacyjną-wszystkie wagony są autonomiczne samodzielne i mogą być wstawiane w dowolne konfiguracje składów pociagów, posiadają zwiększony komfort jazdy dla podróżnych, polegający na zastosowaniu odpowiedniego wyposażenia wewnętrznego, zamkniętego przejścia międzywagonowego, zastosowaniu pudła wagonu o bardzo dużej szczelności ( zwiększenie komfortu dla podróżnych przy osiagnięciu wysokich prędkości), układu siedzeń z podziałem na 3 klasy czyli tzw. klasa ,premium”, posiadająca miejsca siedzace gwarantujące komfort w klasach „biznesowych” stosowanych w dalekobieżnych samolotach, pierwsza klasa (ang.,,First”) i druga klasa (ang. „economy”), możliwości wykonania dodatkowego wyposażenia wewnętrznego, do jakiego należą między innymi punkty informacyjne dla podróżnych, przedział dla dzieci, pomieszczenie dla przechowywania wózków dziecięcych i bistro. Szczególną uwagę poświęcono również możliwości korzystania $\mathrm{z}$ wagonu, posiadającego budowę modułową przez pasażerów niepełnoprawnych poprzez wkomponowanie w konstrukcję urządzeń ułatwiających wsiadanie, miejsc dla pasażerów na wózkach inwalidzkich w pomieszczeniu dla podróżnych oraz specjalną toaletę. Kontener $\mathrm{z}$ urządzeniami jest zabudowany pod podłogą, natomiast zbiornik ze świeżą wodą i agregaty z powietrzem odlotowym na dachu wagonu.

Zgodnie z kartą UIC 660 [14] przez ruch z wysokimi prędkościami rozumie się taki, który jest realizowany z prędkością większą niż $250 \mathrm{~km} / \mathrm{h}$.

Aby można było zrealizować osobowy transport kolejowy z wysokimi prędkościami w zakresie własności dynamicznych pojazdu i bezpieczeństwa całego systemu abstrahujacc od zagadnień prowadzenia pojazdu w torze i na rozjazdach (ten warunek dotyczy wszystkich pojazdów niezależnie od ich przeznaczenia) należy spełnić następujące kryteria wynikające z:

$>$ geometrii styku pomiędzy kołem i szyną

$>$ jakości toru

$>$ własności dynamicznych układu biegowego oraz nadwozia.

\section{Warunki dla ruchu z wysokimi prędkościami ze strony infrastruktury}

Aby można było zrealizować ruch z wysokimi prędkościami należy zapewnić właściwe własności dynamiczne, wynikające z oddziaływania koła i szyny. Cały system ", tor -układ biegowy-pudło wagonu" należy zaliczyć do kompleksowych systemów techniki kolejowej. Parametr, który charakteryzuje wzajemna współpracę określa się jako ekwiwalentną stożkowatość (ang. „equivalent conicity”, niem. ,äquivalente Konizität"). Ekwiwalentna stożkowatość przyjmuje 
się jako bazę odniesienia rzeczywisty punkt styku koło-szyna i wyrażona jest jako tg $\gamma_{\mathrm{e}}$ (lub $\gamma_{\mathrm{e}}$ ) kąta pochylenia stożka ( niem. „Kegelwinkel”) koła o zarysie zewnętrznym wieńca koła o profilu stożkowym. W rzeczywistości wieniec koła posiada zarys zewnętrzny zgodny z karta UIC 510-2 [12] lub PN-EN 13715:2006 [17]. Na rys.1 przedstawiono zestaw kołowy znajdujący się w torze [9].
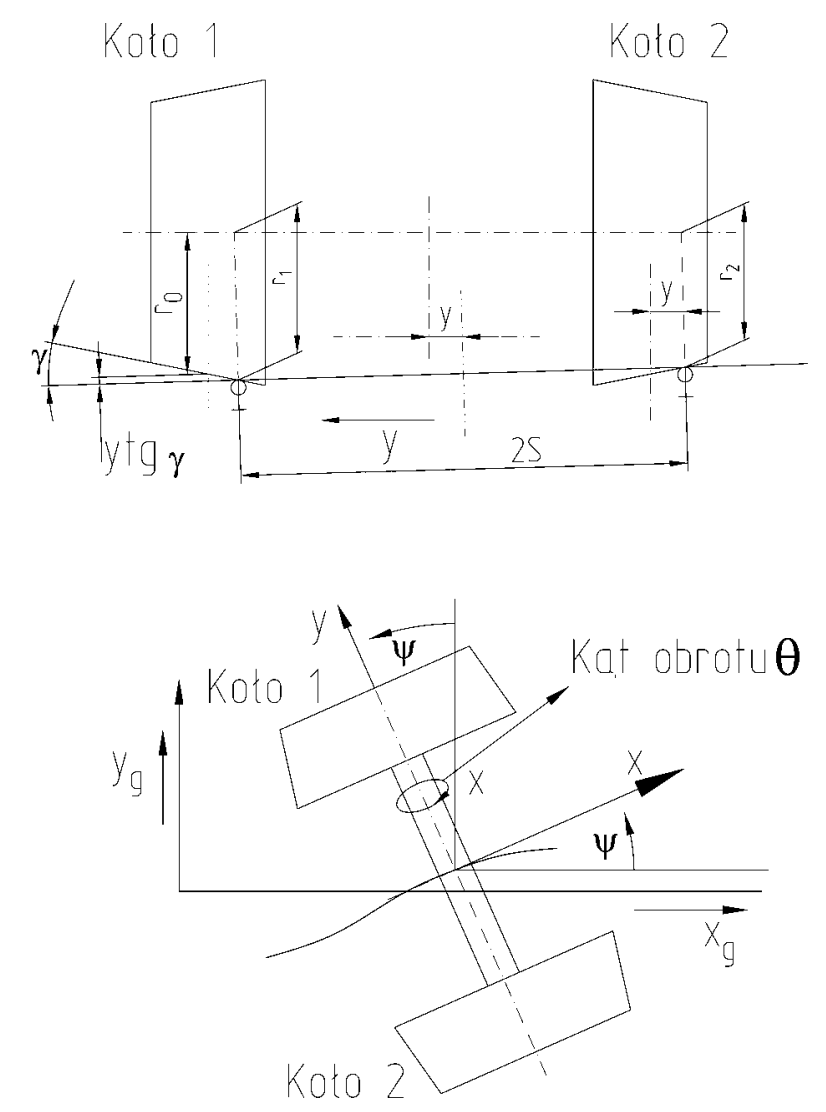

Rys.1. Zjawisko ruchu wężykowania zestawu kołowego w torze wg [9]

Z rys.1 wynika możliwa zmiana faktycznego promienia tocznego w zależności od możliwych przemieszczeń zestawu kołowego w torze tzn. $\pm y_{\mathrm{g}}$. Na podstawie rys.1 można sformułować wzór definiujący ekwiwalentną stożkowatość:

$$
\operatorname{tg} \gamma_{e}=\frac{d r}{2 y_{g}}
$$

gdzie:

dr-przyrost promienia tocznego wskutek ruchu tocznego zestawu kołowego w torze o danym prześwicie, przy czym $d r=r_{1}-r_{2} i$ jest określane $w$ literaturze jako funkcja $\mathrm{f}_{\Delta \mathrm{r}}(\mathrm{y})[2]$

$\mathrm{y}_{\mathrm{g}}$-podwójna amplituda przemieszczenia poprzecznego zestawu kołowego podczas wężykowania zestawu kołowego.

Jak wynika z [2] definicja była podstawą do przyjęcia jej jako obowiązującej w nowej edycji karty UIC 518 [13] i PN-EN 14363: 2005 [19]. Definicja ta brzmi następująco: „Parametrem najlepiej charakteryzującym oddziaływanie stykowe w układzie koło szyna jest ekwiwalentna stożkowatość (tg $\gamma_{\mathrm{e}}$ ), która dla zestawu kołowego poruszającym się pod danym torze jest równa tangensowi kąta stożka tg $\gamma_{\mathrm{e}}$ zestawu kołowego o profilach stożkowych, a ruch poprzeczny ma tę samą długość fali $\lambda$ ruchu wężykowania jak fala danego zestawu. Ekwiwalentna stożkowatość jest zależna od maksymalnej amplitudy $\mathrm{y}_{\mathrm{g}}$ ruchu poprzecznego zestawu kołowego:

$$
\operatorname{tg} \gamma_{e}=f\left(y_{g}\right)
$$

Na ogół ekwiwalentna stożkowatość obliczana jest dla amplitudy $\mathrm{y}_{\mathrm{g}}= \pm 3 \mathrm{~mm} . ”$

Zgodnie z kartą UIC 518 [13] oraz PN-EN 14363: 2005 [19] ekwiwalentna stożkowatość dla ruchu z wysokimi prędkościami musi wynosić:

$>\mathrm{w}$ przedziale prędkości $220 \mathrm{~km} / \mathrm{h}<\mathrm{v} \leq 250$ $\mathrm{km} / \mathrm{h}-\operatorname{tg} \gamma_{\mathrm{e}} \leq 0,30$, co odpowiada kątowi pochylenia zarysu zewnętrznego koła $\gamma_{\mathrm{e}}=16,69^{\circ}$

$>$ w przedziale prędkości $250 \mathrm{~km} / \mathrm{h}<\mathrm{v} \leq 280$ $\mathrm{km} / \mathrm{h}-\operatorname{tg} \gamma_{\mathrm{e}} \leq 0,25$, co odpowiada kątowi pochylenia zarysu zewnętrznego koła $\gamma_{\mathrm{e}}=14,03^{\circ}$

$>$ w przedziale prędkości $280 \mathrm{~km} / \mathrm{h}<\mathrm{v} \leq 350 \mathrm{~km} / \mathrm{h}$ $-\operatorname{tg} \gamma_{e} \leq 0,15$, co odpowiada kątowi pochylenia zarysu zewnętrznego koła $\gamma_{\mathrm{e}}=8,53^{\circ}$.

$\mathrm{Z}$ powyższego zestawienia wynika, że im mniejsza jest ekwiwalentna stożkowatość, tym mniejszy jest kąt stożkowy $\gamma_{\mathrm{e}}$ i z tym większą prędkością może jeździć pojazd, zachowując wymagane własności dynamiczne. Podane wartości ekwiwalentnej stożkowatości obowiązują dla ruchu międzynarodowego, natomiast $\mathrm{w}$ przypadku ruchu krajowego lub bilateralnego z przekraczaniem granic mogą wykazywać wartości z ustalonymi odstępstwami. Jak wynika $\mathrm{z}$ analiz przedstawionych $w$ [35], aby osiagnąc tak niską wartość ekwiwalentnej stożkowatości należy przeprowadzić zabiegi techniczne nie tylko w samym układzie biegowym pojazdu (zastosowanie podwójnych tłumików wężykowania), ale również ze strony infrastruktury. W przypadku czynników, które muszą być podejmowane ze strony infrastruktury należy zaliczyć:

$>$ właściwe tolerowanie prześwitu toru, zwłaszcza na odcinkach prostych; w przypadku trasy szybkiego na kolejach DB-AG stwierdzono, że prześwit toru powinien wynosić $1436 \pm 2 \mathrm{~mm}$ ( przy pochyleniu profilu główki szyny 1:40); stwierdzono na podstawie przeprowadzonych badań dynamicznych, że tor jest najbardziej chroniony przed oddziaływaniem dynamicznym tylko wtedy, gdy prześwit toru nie jest zbyt mały i nie osiaga wartości mniejszych niż $1434 \mathrm{~mm}$ [7]

$>$ poszukiwanie nowych profili główek szyn jak np. profil UIC 60E2 stosowany przez DB AG oraz typu A-G stosowany przez koleje austriackie ÖBB [7];przykład porównania zależności ekwiwalentnej stożkowatości dla trzech różnych 
profilów główki szyny UIC 60 (pochylenie 1:40), UIC 60E2 (pochylenie 1:40) i UIC 60 (pochylenie 1:20) dla prześwitu toru $1435 \mathrm{~mm}$ jest podany na rys.2.

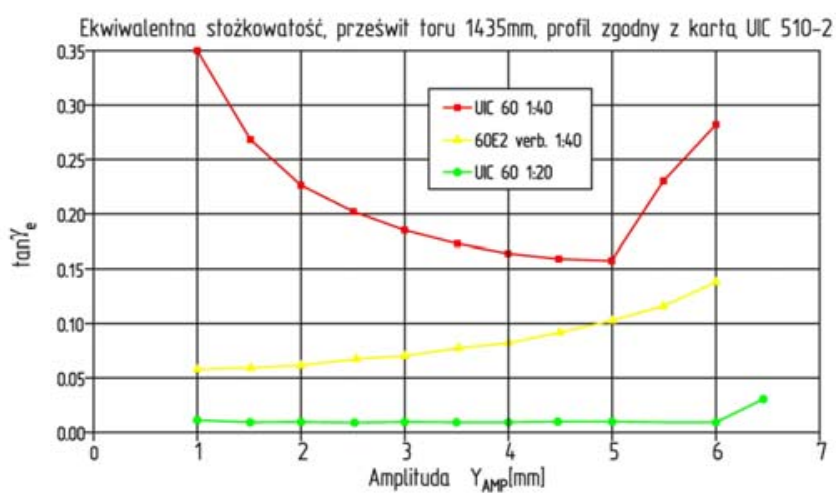

Rys.2. Porównanie zależności ekwiwalentnej stożkowatości w zależności od amplitudy drgań wężykowania zestawu kołowego $\mathrm{Y}_{\mathrm{AMP}}$ dla toru o prześwicie $1434 \mathrm{~mm}$ oraz trzech różnych profilów główek szyn UIC 60 (pochylenie 1:40), UIC 60E2 (pochylenie1:40) oraz UIC 1:20.

Profil główki szyny UIC 1:20 gwarantuje utrzymanie niskiej wartości stożkowatości ekwiwalentnej $\operatorname{tg} \gamma_{\mathrm{e}}<0,05$, co np. posiada zasadniczą zaletę polegającą na niezależności od zmiany prześwitu toru, jednakże posiada również wady polegające między innymi na tym, że:

- dla pojazdów, które nie zostały zaprojektowane dla tak niskich wartości ekwiwalentnej stożkowatości, mogą być narażone na drgania o niskiej częstotliwości

- pochylenie 1:20 zmniejsza znacznie możliwość „centrowania” lub inaczej zajmowania położenia środkowego zestawu kołowego w torze, przez co zwiększa się wrażliwość na poprzeczne odchyłki trasowania toru

- $\quad \mathrm{z}$ powodu bardzo ,płaskiego" przebiegu $\mathrm{f}_{\Delta \mathrm{r}}(\mathrm{y})$ i towarzyszącymi temu niekorzystnymi własnościami dla jazdy w łuku ( bardzo duże wartości przy najmniejszym przejezdnym kinematycznie promieniu łuku $\mathrm{R}_{\min }$ dochodzi do ciagłego nabiegania obrzeża koła na główkę szyny i do bardzo złych własności dynamicznych w kierunku poprzecznym; nieunikniony styk dwupunktowy na zewnętrznej szynie powoduje $\mathrm{w}$ polączeniu $\mathrm{z}$ niewystarczającą różnicą promieni tocznych bardzo duże zużycie na krawędzi główki szyny i na obrzeżu koła nabiegającego

- część główki szyny, która wchodzi podczas przejazdu w styk $\mathrm{z}$ powierzchnią koła jest bardzo wąska ( niem. „Fahrspiegel”), co świadczy o bardzo niekorzystnym rozkładzie obciążenia.
Analizując trasy kolejowe przystosowane do wysokich prędkości na sieci kolejowej SNCF oraz DB-AG można wyciagnąć wniosek, że zakres promieni $\mathrm{R} \leq 600 \mathrm{~m}$ jest znacznie większy na DB-AG i z tego względu zapewnienie właściwej geometrii na łukach jest czynnikiem dominującym przy podejmowaniu decyzji niż na trasach kolei francuskich SNCF; $\mathrm{z}$ tych też względów pochylenie główki szyny 1:20 nie może być zastosowane na sieci kolejowej DB-AG.

$>$ zwiększenie elastyczności nawierzchni kolejowej do $1,0 \div 1,5 \mathrm{~mm} / 20 \mathrm{t}$ poprzez zabudowę sprężystych podkładek pomiędzy stopę szyn a podkład kolejowy oraz maty zainstalowane pod nawierzchnią kolejową na mostach kolejowych. Przykład takiego rozwiązania jest podany na rys. 3 [5].

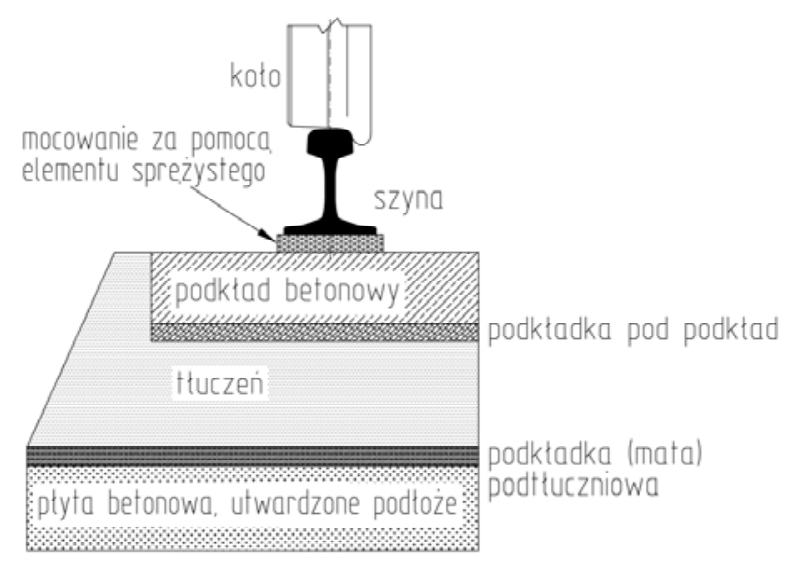

Rys. 3. Przykład zabudowy nawierzchni kolejowej przystosowanej do wysokich prędkości

Tor jest również źródłem wymuszeń kinematycznych drgań pojazdu zgodnie ze wzorem wg [4]:

$$
\ddot{z}(v)=a \cdot\left(\frac{2 \pi}{L} \cdot v\right)^{2}
$$

gdzie:

$\ddot{z}(v)$-przyspieszenie zestawu kołowego w kierunku pionowym, wywołanym nierównościami toru $\mathrm{w}$ postaci rowków $\mathrm{w}$ formie funkcji okresowych

L-długość „fali” nierówności, występującej okresowo w sposób ciagły

a-głębokość nierówności

v- prędkość pojazdu. 
Jak wynika z rys.2 poszukiwanie nowych profili główek szyn dało obiecujące rezultaty, gdyż ekwiwalentna stożkowatość dla profilu szyny UIC 60E2 skojarzonego z profilem powierzchni tocznej koła pojazdu S1002 dla stanu nowego wynosi 0,08 natomiast w przypadku zastosowania profilu szyny UIC 60 przyjmuje wartość 0,18 . W wyniku $\mathrm{z}$ dwuletnich badań eksploatacyjnych przeprowadzonych przez DB-AG na trasie Köln-Rhein am Meinz i przeprowadzonych pomiarów w różnych punktach pomiarowych za pomocą manualnego przyrządu do pomiaru profilów, ekwiwalentna stożkowatość dla profilu szyny UIC 60E2 nie tylko nie zwiększyła się, ale wykazała mniejsze wartości, co należy tłumaczyć tym że profil główki szyny uległ lekkiemu zeszlifowaniu. Ponieważ różnica promieni zmienia się w sposób ciagły wraz z przesunięciem poprzecznym, własności dynamiczne pojazdu na łuku toru z szynami UIC 60E2 są znacznie korzystniejsze aniżeli na łuku toru z szynami UIC 60. Minimalny przejezdny promień toru z szynami UIC 60E2 pod względem kinematycznym ( $\mathrm{z}$ zachowaniem własności toczenia) wynosi $220 \mathrm{~m}$, natomiast w przypadku torów z szynami UIC 60 tylko $500 \mathrm{~m}$. Ww. kierunek rozwojowy jest jak najbardziej słuszny, gdyż jak wykazały badania doświadczalne profil główki szyny zmienia się znacznie wolniej w zależności od czasu, aniżeli profil koła.

W związku z wyżej wymienionymi czynnikami bardzo ważne jest utrzymanie infrastruktury, mającym na celu między innymi usuwanie skutków zużycia szyn za pomocą ich szlifowania, służąca odtworzenie profilu [8].

Kolejnym problemem $\mathrm{z}$ jakim musieli się zmierzyć konstruktorzy infrastruktury kolejowej był przejazd pociagów przystosowanych do wysokich prędkości przez mosty kolejowe. Jak okazało się z doświadczeń kolei francuskich SNCF, podczas przejazdu zespołów trakcyjnych lub pociagów przez wąskie konstrukcje mostów kolejowych o krótkiej rozpiętości powstawało regularne wzbudzenie przez zestawy kołowe, które mogło doprowadzić powyższe konstrukcje do rezonansu. Wskutek tego przeciążenia konstrukcji mostów kolejowych, dochodziło do znacznego pogorszenia się jakości torów, których naprawa nie gwarantowała spełnienia wymaganych kryteriów na dłuższy okres czasu. W związku z tym powołano w ramach UIC komisję rzeczoznawców ERRI D214, której zadaniem było opracowanie wytycznych dla zapewnienia wytrzymałości konstrukcji nośnych mostów kolejowych na działanie obciążeń dynamicznych. Po zakończeniu prac ww. komisji przedstawiono wyniki prac, które zakwalifikowano $\mathrm{w}$ następujące zagadnienia:

$>$ metodyka dla analizy dynamicznej mostów

$>$ układ obciążeń do projektowania mostów kolejowych przeznaczonych do wysokich prędkości
$>$ minimalne wartości tłumienia dla mostów stalowych, betonowych i wykonanych z tworzyw kompozytowych

> wartości granicznych przyspieszeń dla nawierzchni kolejowej na moście oraz dla toru beztluczniowego [11].

\section{Wlasności dynamiczne ze strony pojazdu}

Jednym z czynników kształtujących dynamikę pojazdu jest konstrukcja pojazdu osobowego, a w szczególności układu biegowego.

Do istotnych czynników, kształtujących dynamikę pojazdów szynowych należą:

$>$ masa nieusprężynowana układu biegowego, która powinna przyjmować możliwie najniższe wartości, przy czym znaczenie tego czynnika jest znacznie większe aniżeli całkowita masa własna pojazdu

> wykonanie zestawów kołowych $\mathrm{z}$ dużą dokładnością niewyważenia dynamicznego bicia wieńca powierzchni tocznej oraz bocznej zarysu zewnętrznego wieńca koła zgodnie $\mathrm{z}$ PN-EN 13262:2005 [16]; dokładność wykonania osi zgodnie z PN-EN13261 [15]

$>$ zastosowanie skutecznych, wzmocnionych aktywnych elementów thumienia w układzie biegowym $\mathrm{w}$ pierwszym $\mathrm{i}$ drugim stopniu usprężynowania

$>$ odpowiednio „miękkie” połączenie zestawów kołowych wózka z ramą układu biegowego

$>$ odpowiednio „miękkie” połączenie pudła wagonu z układami biegowymi gwarantującymi wystarczające przemieszczenia $\mathrm{w}$ kierunku pionowym, poprzecznym oraz wzdłużnym

$>$ struktura pudła wagonu osobowego, która nie posiada częstotliwości własnych w zakresie, w którym mogą być wzbudzone przez układ biegowy i oddziaływanie koło/szyna ( $\mathrm{w}$ szczególności drgania giętne oraz drgania giętno-skrętne)

$>$ znacznie większe zdolności tłumiące pojazdu na połączeniu pudło wagonu $\mathrm{z}$ wyposażeniem wewnętrznym.

$\mathrm{W}$ p.2 przedstawiono wymagania $\mathrm{w}$ zakresie infrastruktury, aby spełnić wymagania wartości ekwiwalentnej stożkowatości dla ruchu z wysokimi prędkościami. W przypadku pojazdu istnieje możliwość doboru odpowiedniego zarysu zewnętrznego wieńca koła, zwłaszcza w rejonie powierzchni tocznej oraz obrzeża koła.

$\mathrm{Na}$ sieci DB-AG przeprowadzono doświadczenia $\mathrm{z}$ zespołem trakcyjnym wysokich prędkości ICE 2 ( niem. „Intercity Experimentall”), w którym zastosowano:

$>$ dwa wagony wyposażone $\mathrm{w}$ koła $\mathrm{z}$ zarysem wieńca koła o nazwie „profil zużyty TGV”, 
Rozwój ekwiwalentnej stożkowatości dla różnych profili kól dla zespołu trakcyjnego ICE 2 w zależności od przebiegu $[\mathrm{km}]$, zarejestrowany podczas eksploatacji obserwowanej

\begin{tabular}{|c|c|c|c|c|c|c|}
\multicolumn{9}{c|}{ Tabela 1 } \\
\hline Profil/przebieg & $\mathbf{3 0 0 0} \mathbf{~ k m}$ & $\mathbf{4 2 0 0 0}$ & $\mathbf{6 3 0 0 0}$ & $\mathbf{9 3 0 0 0}$ & $\mathbf{1 2 7} \mathbf{0 0 0}$ & $\mathbf{1 5 8 0 0 0}$ \\
\hline Zużyty TGV & 0,2 & 0,23 & 0,24 & 0,27 & 0,27 & \\
\hline S1002-1421 & 0,10 & 0,16 & 0,19 & 0,23 & 0,23 & 0,23 \\
\hline S 1002-1423 & 0,15 & 0,19 & 0,20 & 0,23 & 0,23 & 0,23 \\
\hline
\end{tabular}

$>$ dwa wagony wyposażone w koła z zarysem wieńca koła o nazwie „profil ORE S1002” ( od 1973 roku uznany przez DB jako profil standardowy) i z aktywną odległością zewnętrznych powierzchni obrzeży kół 1421 $\mathrm{mm}$ ( ang. ,the outer distance between the wheel flanges measured at the point 10 millimeters below the running treads", niem. , Spurmass")

> wagon restauracyjny wyposażony $\mathrm{w}$ koła $\mathrm{z}$ zarysem wieńca koła o nazwie ,profil ORE S1002" i z aktywną odległością zewnętrznych powierzchni obrzeży kół $1423 \mathrm{~mm}$.

Profil „zużyty TGV” został wybrany z uśrednienia różnych zmierzonych profili TGV. W tabeli 1 przedstawiono rozwój ekwiwalentnej stożkowatości dla różnych profili kół dla amplitudy wężykowania $\mathrm{y}_{\mathrm{g}= \pm} 3$ $\mathrm{mm}$, przy czym pomiary były przeprowadzone dla zespołu trakcyjnego na torze z szynami typu UIC $60 \mathrm{i}$ posiadającym prześwit $1435 \mathrm{~mm}$ [11].

$\mathrm{Z}$ wyników badań przedstawionych $\mathrm{w}$ tabeli 1, wynika że „zużyty profil TGV” koła nie wykazał stabilności kształtu na sieci DB-AG. Ponieważ wartość ekwiwalentnej stożkowatości ciagle rosła i przekroczyła dopuszczalną wartość 0,25 , zestawy kołowe musiały być reprofilowane po przebiegu wynoszącym około $130000 \mathrm{~km}$.

Warunek ekwiwalentnej stożkowatości tg $\gamma_{\mathrm{e}} \leq 0,25$ dla zakresu prędkości $250 \leq \mathrm{V}<280 \mathrm{~km} / \mathrm{h}$ jest spełniony dla profili ORE S1002. Wartość ekwiwalentnej stożkowatości dla tych profili wprawdzie rosła, ale potem wykazała ustabilizowaną wartość po przebiegu wynoszącym $100000 \mathrm{~km}$. Ponieważ próby ze , zużytym profilem TGV" dały negatywny rezultat, postanowiono przeprowadzić następne badania $\mathrm{z}$ nowym profilem koła o nazwie „, GV 1/40”. W tym celu w 1999 roku przygotowano zespół trakcyjny ICE1 z kołami z ww. profilem. Niniejszy profil wykazywał bardzo duże rezerwy zużycia dzięki bardzo małej wartości ekwiwalentnej stożkowatości ( $\left.\tan \gamma_{\mathrm{e}}= \pm 0,025\right)$. Zgodnie $\mathrm{z}$ oczekiwaniami ekwiwalentna stożkowatość wzrosła już po paru kilometrach przebiegu i ustabilizowała się na poziomie poniżej $0,2 \mathrm{z}$ aktywną odległością zewnętrznych powierzchni obrzeży kół $1421 \mathrm{~mm}$ aż do zakończenia badań tzn. do $180000 \mathrm{~km}$ przebiegu. Stwierdzono jednak podczas tych badań złe własności dynamiczne zespołu trakcyjnego podczas jazdy przez łuki toru. Niektóre zestawy kołowe musiały być przetoczone po $120000 \mathrm{~km}$ przebiegu ponieważ wymiar obrzeża $\mathrm{q}_{\mathrm{R}}$ zbliżył się do granicznego kryterium wynoszącego $6,5 \mathrm{~mm}[11]$.

\section{Tendencje rozwojowe układów biegowych przy- stosowanych do wysokich prędkości}

Istotnymi czynnikami kształtującymi tendencje rozwojowe układów biegowych przystosowanych do wysokich prędkości wynikają z p.3. Aby zmniejszyć masę układu biegowego do wartości 6t, należy zwrócić uwagę na zastosowanie nowych materiałów na ramę wózka, do jakich należą między innymi materiały kompozytowe, wzmocnione włóknami szklanymi. Rama ta została wyprodukowana przez firme MBB w Donauwörth i przeszła pozytywnie badania statyczne oraz zmęczeniowe a jej przydatność eksploatacyjna została potwierdzona przez eksploatację w układzie biegowym zespołu trakcyjnego (około $2 \mathrm{mi}$ liony kilometrowego przebiegu). Do braku wdrożenia ramy do produkcji seryjnej przyczyniły się bardzo wysokie koszty wytwarzania. Należy jednak wziąć pod uwagę, że udział ramy wózka w ogólnej masie układu biegowego wynosi około $20 \div 30 \%$, natomiast poważny udział przypada również na zestawy kołowe, wyposażenie hamulcowe, elementy usprężynowania i thumienia oraz oparcia pudła. Pewną możliwość rozwiązań konstrukcyjnych w tym zakresie oferują tarcze aluminiowe, które pozwalają na zmniejszenie mas nieusprężynowanych. Tarcza hamulcowa wykonana $z$ aluminium pozwala na zmniejszenie masy o około 45 $\mathrm{kg}$, w stosunku do tarczy wykonanej ze staliwa. Jak dowodzą doświadczenia związane $\mathrm{z}$ eksploatacją zespołu trakcyjnego ICE 1 na DB AG powoduje to oszczędność rzędu $180 \mathrm{~kg}$ na zestaw kołowy (zastosowano 4-ry tarcze hamulcowe na jednym zestawie kołowym). Zestawy kołowe, wyposażone w koła oraz osie, wykonane ze stali nie pozwalają na znaczące oszczędności masowe przy danej średnicy tocznej koła. Przejście na niższe średnice toczne koła od 920 $\mathrm{mm}$ do 730/680 mm jest możliwe, ale jest związane ze zmniejszeniem dopuszczalnego nacisku zestawu kołowego na szyny do 16 t zgodnie z kartą UIC 510-2 [12]. Decydującym kryterium są w tym przypadku naciski powierzchniowe pomiędzy kołem i szyną, które w przypadku przekroczenia wartości dopuszczalnych w wyniku większego wytężenia materiału moga prowadzić do uszkodzeń na powierzchni tocznej ( np. wykruszenia i rozwalcowanie powierzchni tocznej). Mniejsze średnice kół zestawów kołowych oznaczają jednocześnie mniejsze średnice tarcz hamulcowych, co może się przyczyniać do zwiększenia temperatur na powierzchni współpracy tarcza hamulcowa okładzina cierna podczas procesów hamowania i możliwości występowania zakłóceń w eksploatacji, powo- 


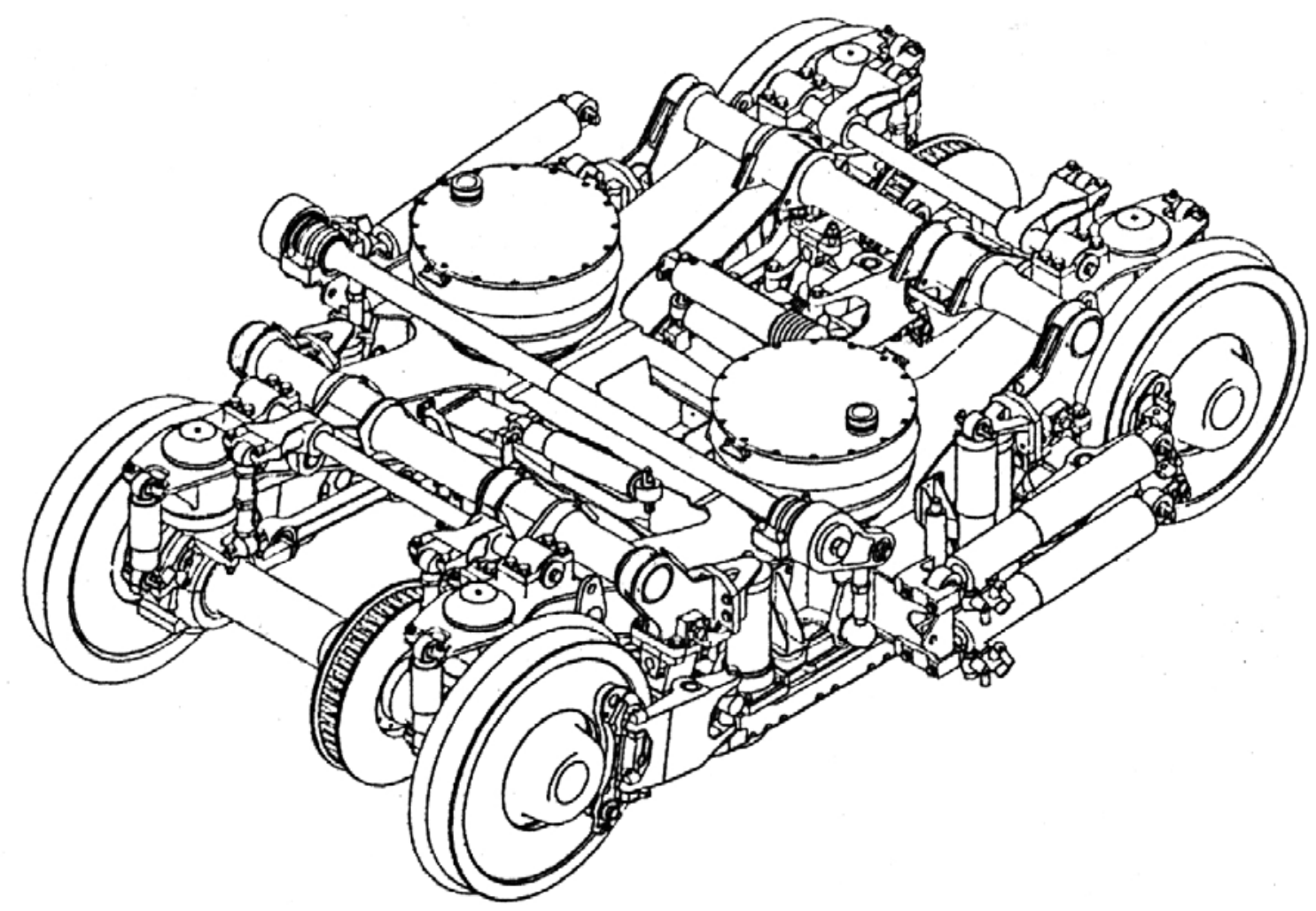

Rys.4. Wózek typu „Sumitomo” z wewnętrznie ułożyskowanymi zestawami kołowymi wg [6]

dujących między innymi zatrzymanie pociagu wskutek wykrycia tego zjawiska przez urządzenia detekcyjne typu FBOA (niem.,,Festbremsortungsanlage”), umieszczone pomiędzy w strefie pomiędzy obydwoma tokami szyn [8]. Kolejnym zabiegiem konstrukcyjnym, który można wykonać aby zmniejszyć masę własną pojazdu, jest również zastosowanie układu biegowego z wewnętrznie ułożyskowanymi zestawami kołowymi. Wówczas konstrukcja posiada kompaktową budowę zestawów kołowych $\mathrm{z}$ jednoczesnym ograniczeniem wartości nieusprężynowanych mas własnych. Przykładem takiego rozwiązania jest wózek „Sumitomo” przedstawiony na rys.4, który posiada masę własną mniejszą od $5 \mathrm{t}$.

Wadą takiego rozwiązania jest między innymi brak kompatybilności z urządzeniami typu HOA (niem. „Heissläuferortungsanlage” lub „Heisslagerortungsanlage") do wykrywania przegrzanych łożysk tocznych, które są rozmieszczone na zewnątrz toru. W takim przypadku rozwiązania układu biegowego konieczne jest zainstalowanie urządzeń do detekcji na pojeździe, zgodnie z p.5.4. karty UIC 660 [14]. Jak wynika z dzisiejszych doświadczeń zbudowanie układu biegowego w klasycznej formie tzn. z ułożyskowaniem zewnętrznym i całkowitą masą poniżej $6 \mathrm{t}$ może być w ogóle nierealne na obecnym etapie rozwoju techniki. Masa wyposażenia hamulcowego (tarcze hamulcowe na kole, na osi oraz elektromagnetyczny hamulec szynowy, w przyszłości hamulec na prądy wirowe) wynosi ok. $40 \%$ masy całkowitej wózka.
Bardzo istotnym czynnikiem ceny układu biegowego jest emisja hałasu podczas jazdy wagonu osobowego, która obciąża środowisko naturalne. Spełnienie kryteriów emisji hałasu przedstawionych w karcie UIC 660 [14] jest możliwe pod warunkiem zastosowania dodatkowych zabiegów konstrukcyjnych w układzie biegowym. Zestawienie wartości wymaganych przez Warunki Techniczne Interoperacyjności TSI ( ang. „Technical Specifications for Interoperability”, niem. „Technische Spezifikationen für die Interoperabilität") jest przedstawione w tabeli 2.

Wartości podane w kolumnie 3 tabeli 1 obowiązywały w warunkach TSI do końca 2002 roku. Jak wykazały późniejsze prace nad projektem wartości te okazały się zbyt trudne do spełnienia na obecnym poziomie technicznym, w związku z czym zaproponowano nowe wartości, które obowiązują od 2007 roku wg [3]. Jako główne źródło emisji hałasu należy uznać tarczę koła. W związku z tym do zabiegów konstrukcyjnych zmniejszających emisję hałasu można zaliczyć zastosowanie zestawów kołowych z tłumikiem hałasu. Tłumik hałasu jest zainstalowany po wewnętrznej stronie tarczy koła i wykonany z materiałów kompozytowych. Zainstalowanie thumika po zewnętrznej stronie tarczy koła jest możliwe pod względem technicznym i na pewno przyczynia się dodatkowo do zmniejszenia emisji hałasu, ale niestety utrudnia reprofilację (odtworzenie) zarysu zewnętrznego wieńca koła. Dodatkowym rozwiązaniem może być zastosowanie farb posiadających własności tłumiące na tarczy koła oraz na osi zestawu kołowego. 
Zestawienie wymagań i stanu faktycznego emisji hałasu dla pociągów i zespołów przeznaczonych do wysokich prędkości dla DB AG wg [3]

\begin{tabular}{|c|c|c|c|}
\hline L.p. & Prędkość $[\mathbf{k m} / \mathbf{h}]$ & $\begin{array}{c}\text { Kryterium natę- } \\
\text { żenia halasu } \\
\mathbf{d B}(\mathbf{A})\end{array}$ & $\begin{array}{c}\text { Wartości rzeczywiste } \\
\text { natężenia hałasu } \\
\mathbf{d B}(\mathbf{A})\end{array}$ \\
\hline 1. & 200 & 88 & - \\
\hline 2. & 250 & $89(88)$ & $87 \div 94$ \\
\hline 3. & 300 & $92(91)$ & $91 \div 95$ \\
\hline 4. & 320 & $94(92)$ & $92 \div 96$ \\
\hline
\end{tabular}

Czynniki zmniejszające emisję hałasu można podzielić na cztery grupy:

$\Rightarrow$ zmniejszenie wymuszenia (chropowatość powierzchni tocznej koła oraz szyny, zastosowanie hamulców tarczowych)

$\Rightarrow$ zastosowanie kół o zmniejszonej emisji hałasu ( zastosowanie kół usprężynowanych, optymalizacja kształtu koła i jego geometrii)

$\Rightarrow$ zastosowanie toru o zwiększonej zdolności thumienia drgań ( tor o optymalnej sztywności, zwiększona tłumienność podkładek pod szyny, zwiększona tłumienność szyny, optymalny kształt szyny i thumienie)

$\Rightarrow$ zastosowanie ekranów dźwiękochłonnych.

Na rys. 5 przedstawiono poziom pomierzonego ciśnienia akustycznego w zależności od prędkości dla różnych zespołów trakcyjnych, przystosowanych do wysokich prędkości. Pomiar przeprowadzono w odległości $25 \mathrm{~m}$ od pojazdu.

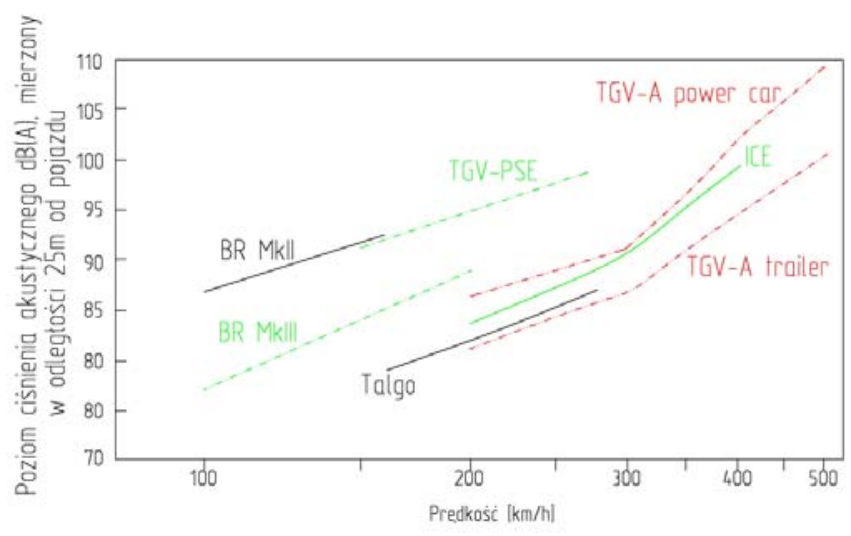

Czlony trakcyjne: BR MKII, TGV-PSE i TGV-A posiadają hamulce klockowe

Człony pośrednie: BR MK III, ICE, Talgo i TGV-A posiadają hamulce tarczowe i bębnowe

Rys.5. Wyniki pomiaru ciśnienia akustycznego w zależności od prędkości dla zespołów trakcyjnych BR Mk II, TGV-PSE, TGVA, BR Mk III, ICE, Talgo wg [10]

Jak wynika $\mathrm{z}$ rys. 5 emisja hałasu zespołów trakcyjnych wyposażonych $\mathrm{w}$ hamulce tarczowe ( zespoły trakcyjne typu TGV-A posiadają hamulce klockowe jedynie na członach trakcyjnych) przy prędkości 300 $\mathrm{km} / \mathrm{h}$ jest porównywalna $\mathrm{z}$ tradycyjnymi pojazdami,
Tabela 2

wyposażonymi w hamulce klockowe przy prędkościach jazdy $140 \div 160$ $\mathrm{km} / \mathrm{h}$. Przy wysokich prędkościach dużego znaczenia nabiera hałas pochodzenia aerodynamicznego, którego poziom wzrasta znacznie szybciej wraz z prędkością aniżeli hałas pochodzenia tocznego ( niem. „Rollgeräusch").

Określają to następujące zależności tzn. „60 lg v" dla hałasu aerodynamicznego oraz ,30 lg v" dla hałasu tocznego. W za$\mathrm{kresie}$ do $300 \mathrm{~km} / \mathrm{h}$ dominuje hałas pochodzenia tocznego, natomiast powyżej tej prędkości hałas pochodzenia aerodynamicznego.

Rama wózka jako podstawowy ustrój nośny powinna spełniać wymagania wytrzymałości statycznej (obciążenia nadzwyczajne, obciążenia eksploatacyjne) oraz wytrzymałości zmęczeniowej zgodnie z wymaganiami normy PN-EN 13749:2005 [18]. Jej wytrzymałość powinna być dowiedziona badaniami stanowiskowymi na jednym egzemplarzu ramy, przy czym wprowadzenie sił powinno być możliwie zrealizowane w taki sposób, aby zasymulować eksploatację w rzeczywistych warunkach czyli np. oprócz zasadniczych obciążeń do jakich zalicza się siły pionowe, siły boczne (wynikające $\mathrm{z}$ jazdy przez łuki lewe oraz prawe), siły kinematycznego wymuszenia wynikające $z$ przejazdu przez tor wichrowaty należy rozważyć dodatkowe wprowadzenie sił hamulcowych ( przyłożonych we wspornikach do zamocowania mechanizmów zaciskowych i pochodzących od hamowania nagłego pojazdu i wynoszących ogólnie $10^{6}$ cykli obciążeń w czasie całego okresu eksploatacji pojazdu), od thumików pionowych, poprzecznych oraz wężykowania itp., zwłaszcza jeśli oceni się na etapie badań statycznych że ich wpływ na wytrzymałość zmęczeniową może być znaczący. Rezygnacja $\mathrm{z}$ wprowadzenia dodatkowych obciążeń $w$ badaniach zmęczeniowych musi być uzasadniona ich ewentualnym małym wpływem na ogólne wytężenie konstrukcji w poszczególnych punktach pomiarowych na podstawie wyników pomiarów uzyskanych podczas badań statycznych. Badania zmęczeniowe, które są przeprowadzone w ten sposób mogą przyczynić się do optymalizacji kształtu oraz masy ustroju nośnego.

Badania zmęczeniowe przeprowadza się $\mathrm{w}$ zakresie $10^{7}$ cykli w trzech zakresach obciążeń:

$>$ zakres I- $6 \times 10^{6}$ cykli obciążeń,

$>$ zakres II- $2 \times 10^{6}$ cykli obciążeń, zwiększonych o $20 \%$ w stosunku do obciążeń z cyklu I,

$>$ zakres III $-2 \times 10^{6}$ cykli obciążeń zwiększonych o $40 \%$ w stosunku do obciążeń z cyklu I.

Zapoczątkowana w latach 70-tych tendencja rozwojowa, aby wykonywać ramy o małej sztywności skrętnej z usprężynowaniem pierwszego stopnia o małej po- 
datności, które zapewniają bezpieczny przejazd pojaz$\mathrm{du}$ przez tory wichrowate $\mathrm{w}$ warunkach quasistatycznych oraz wykazują małe naprężenia od wymuszenia typu kinematycznego, spowodowanego przez wichrowatość toru spowodowało dość duże obciążenia w niektórych częściach układu biegowego, zwłaszcza układu hamulcowego, powodując jego zużycia.

\section{Wnioski}

Na podstawie przeprowadzonych analiz można stwierdzić, że ruch $z$ wysokimi prędkościami można zrealizować wspólnym wysiłkiem infrastruktury oraz producentów pojazdów. Wspólnymi zagadnieniami technicznymi dla obydwu pionów technicznych, jakie pojawiają się przy ruchu osobowym jest zapewnienie prawidłowych własności dynamicznych pojaz$\mathrm{du}$ ( zapewnienie odpowiednich wartości ekwiwalentnej stożkowatości) oraz walka $z$ hałasem, emitowanym do otoczenia przez pociagi osobowe lub zespoły trakcyjne. Współpraca w tym zakresie służy nie tylko osiagnięciu zamierzonego celu, jakim jest wdrożenie ruchu $\mathrm{z}$ wysokimi prędkościami do eksploatacji komercyjnej, ale zwiększenie żywotności infrastruktury. Jednym $z$ istotniejszych czynników oceny przydatności pojazdu do wysokich prędkości jest między innymi układ biegowy. Na szczególną uwagę w analizie tego zagadnienia zwraca między innymi współpracy torukład biegowy. Drgania wężykowania, które mogą się pojawić pomiędzy pudłem wagonu oraz wózkami można wythumić poprzez wzmocnienie thumienia stosując dwie pary podwójnych tłumików (po dwa na stronę), leżących naprzeciw siebie. Skuteczność tego rozwiązania jest potwierdzona przez zastosowanie $\mathrm{w}$ innych układach biegowych, przystosowanych do wysokich prędkości. Ważnym zagadnieniem jest również oddziaływanie koło-szyna, które w przypadku musi być przede wszystkim opanowane przez zapewnienie bardzo dużej dokładności wykonania kół (maksymalne zapewnienie okragłości powierzchni tocznych, bicie zarysu zewnętrznego wieńca koła, dopuszczalna wartość niewyważenia dynamicznego kół i całego zestawu kołowego). Kolejnym problemem, jaki wyłania się w układach biegowych jest problem emisji hałasu. Okazuje się, że samo zastosowanie hamulców tarczowych, które $\mathrm{w}$ porównaniu $\mathrm{z}$ hamulcami klockowymi posiadają istotną zaletę $\mathrm{w}$ tym zakresie jest niewystarczające. Konieczna jest dalsza optymalizacja konstrukcji w tym zakresie ( thumiki hałasu, farby thumiące drgania materiałowe). Cały czas aktualny jest problem mas nieusprężynowanych. Obniżenie tej masy stanowi dalej zadanie dla konstruktorów układów biegowych tego typu.

\section{Literatura}

[1]Adam H.D, Simbürger A., Oreski W.: Viaggio ComfortIntercity-Reisezugwagen für das 21 Jahrhundert. Eisenbahntechnische Rundschau. Mai 2008. Nr.05
[2] Bergander N., Dendl G., Nefzger A., Nicklisch D.: Die Entwicklung von Rad-Schienenprofilen. ZEV-RAIL Glasers Annalen.10.2003.

[3] Gessner R.: Reduktion des Schienenverkehrlärms. Eisenbahningenieur Nr. 58, 3/2007.

[4] Hempe T., Siefer T.: Schienenschleifen als Bestandteil einer technisch-wirtschaftlichen Gleisstandhlatung. ZEVrail. Glasers Annalen. Nr. 131.03.2007

[5] Lichtenberger B.: Das System Gleis und seine Instandhaltung. Eisenbahningenieur. Nr.58 1/2007

[6] Madeyski T.: Fahrwerkstechnik- im Zusammenwirken mit dem Fahrweg und dem Fahrzeugkasten. Eisenbahntechnische Rundschau Nr. 48. September 1999.

[7] Müller R: Aktuelle Probleme der Berührungsgeometrie Rad/Schiene. ZEV+DET Glasers Annalen.02/03 2000.

[8] Scheunemann E., Kölbe T., Müller R.: Geometrie Rad/Schiene, ein gemeinsames Thema für Fahrzeug und Fahrweg. ZEVRail Glasers Annalen Nr.129. Tagungsband SFT Graz 2005

[9] Sobaś M.: Ekwiwalentna stożkowatość styku koło-szyna i jej znaczenie we współczesnej analizie własności dynamicznych pojazdu szynowego. Pojazdy Szynowe Nr $1 / 2005$.

[10] Thompson D., Janssens M., Dittrich M.: Rollgeräusche durch den Rad/Schiene-Kontakt. Beurteilung von Lärmminderungsmaßnahmen. ZEV+DET Glasers Annalen $\mathrm{nr}$ 121, 02/03.1997.

[11] Zacher M.: Erfahrungen über das Zusammenwirken von Fahrzeug und Fahrweg im Hochgeschwindigkeitsverkehr bei der Deutschen Bahn AG. ZEVrail Glasers Annalen $\mathrm{nr}$ 132, 6/7.2008.

[12] Karta UIC 510-2: Pojazdy doczepne. Warunki dla stosowania kół o różnych średnicach $w$ układach biegowych różnego typu. 4-te wydanie, kwiecien 2002.

[13] Karta UIC 518: Badania i homologacja pojazdów szynowych z punktu widzenia właściwości dynamicznych, bezpieczeństwa jazdy, obciażenia toru i parametrów biegowych. 3-cie wydanie, październik 2005.

[14] Karta UIC 660: Przepisy dotyczace zapewnienia technicznej kompatybilności dla pociagów dostosowanych do wysokich prędkości. Wydanie 2, sierpień 2002.

[15] PN-EN 13261:2004: Kolejnictwo-Zestawy kołowe $i$ wózki-Osie- Wymagania dotyczace wyrobu

[16] PN-EN 13262:2005: Kolejnictwo-Zestawy kołowe $i$ wózki- Koła-Wymagania dotyczace wyrobu

[17] PN-EN 13715: 2006: Kolejnictwo-Zestawy kołowe $i$ wózki-Koła-Zarys zewnętrzny koła

[18] PN-EN 13749:2005: Kolejnictwo-Zestawy kołowe $i$ wózki-Metody określania wymagań konstrukcyjnych dla ram wózków

[19] PN-EN 14363:2005: Kolejnictwo- Badania własności dynamicznych przed dopuszczeniem pojazdów szynowych. Badania własności biegowych i próby stacjonarne. 